\title{
PENYUSUNAN STRATEGI E-GOVERNMENT BERBASIS KERANGKA KERJA PEMERINGKATAN E-GOVERNMENT INDONESIA (PEGI) DI LEMBAGA PENERBANGAN DAN ANTARIKSA NASIONAL
}

\author{
Fahmi Alusi ${ }^{1}$ dan Dana Indra Sensuse ${ }^{2}$ \\ ${ }^{1}$ Biro Kerjasama dan Humas, LAPAN \\ ${ }^{2}$ Fakultas Ilmu Komputer, Universitas Indonesia \\ Email: fahmialusi@lapan.go.id; dana@cs.ui.ac.id
}

\begin{abstract}
People's presures for establishing good governance motivate the government to be able quickly determine a right strategy to accelerate achievement of the government goals. One of strategies implemented in government is developing e-government, as stated in the Presidential Instruction No. 3 of 2003 on National Policy and Strategy Development of e-government. A framework used to measure level of development and implementation of e-government in Indonesian government institutions is PeGI (The ranking of e-government of Indonesia). To be able perform the implementation and development of e-government in a timely and effectively, it needs some strategies. This research aims to devise an e-government development strategy based on the PeGI framework by doing a case study on the National Institute of Aeronautics and Space (LAPAN). The methodology used is descriptive qualitative with data collection methods including document analysis, observations, and focus group discussion (FGD). Based on the analysis, it is found that the level of e-government implementation in LAPAN today is 1.88 while the level of e-government implementation expected is 3.18 . Finally, this study described the strategies in LAPAN to reach the level of implementation of e-government as expected.
\end{abstract}

Keywords: e-government, PeGI, e-government develompment strategy

\begin{abstract}
Abstrak
Tekanan Rakyat untuk membangun pemerintahan yang baik memotivasi pemerintah untuk dapat dengan cepat menentukan strategi yang tepat untuk mempercepat pencapaian tujuan pemerintah. Salah satu strategi yang diterapkan dalam pemerintahan sedang mengembangkan e-government, sebagaimana tertuang dalam Instruksi Presiden Nomor 3 Tahun 2003 tentang Kebijakan dan Strategi Nasional Pengembangan e-government. Kerangka yang digunakan untuk mengukur tingkat perkembangan dan implementasi e-government di lembaga-lembaga pemerintah Indonesia adalah PEGI (The peringkat egovernment of Indonesia). Untuk dapat melakukan implementasi dan pengembangan e-government secara tepat waktu dan efektif, diperlukan beberapa strategi. Penelitian ini bertujuan untuk menyusun strategi pengembangan e-government berdasarkan kerangka PEGI dengan melakukan studi kasus pada National Institute of Aeronautics dan Antariksa (LAPAN). Metodologi yang digunakan adalah deskriptif kualitatif dengan metode pengumpulan data termasuk analisis dokumen, observasi, dan focus group discussion (FGD). Berdasarkan hasil analisis, ditemukan bahwa tingkat pelaksanaan egovernment di LAPAN saat ini adalah 1,88 sedangkan tingkat implementasi e-government diharapkan 3.18. Akhirnya, penelitian ini menggambarkan strategi di LAPAN untuk mencapai tingkat pelaksanaan e-government seperti yang diharapkan.
\end{abstract}

Kata Kunci: e-government, PEGI, strategi diharapkan pengembangan e-government

\section{Pendahuluan}

Tuntutan masyarakat akan terbentuknya kepemerintahan yang bersih, akuntabel dan transparan, mendorong pemerintah untuk segera melakukan perubahan terhadap proses bisnisnya, hal ini demi mewujudkan tata pemerintahan yang baik (good governance). Sebagai salah satu upaya dalam percepatan mewujudkan good governance pemerintah melaku- kan pengembangan e-government. E-Government adalah penggunaan teknologi informasi yang dapat meningkatkan hubungan antara pemerintah dan pihak lain yang terkait seperti masyarakat, pelaku bisnis dan instansi pemerintah lain. [1] Adanya pengembangan e-government dapat meningkatkan efisiensi, efektifitas, transparansi dan akuntabilitas dalam penyelenggaraan pemerintahan. 


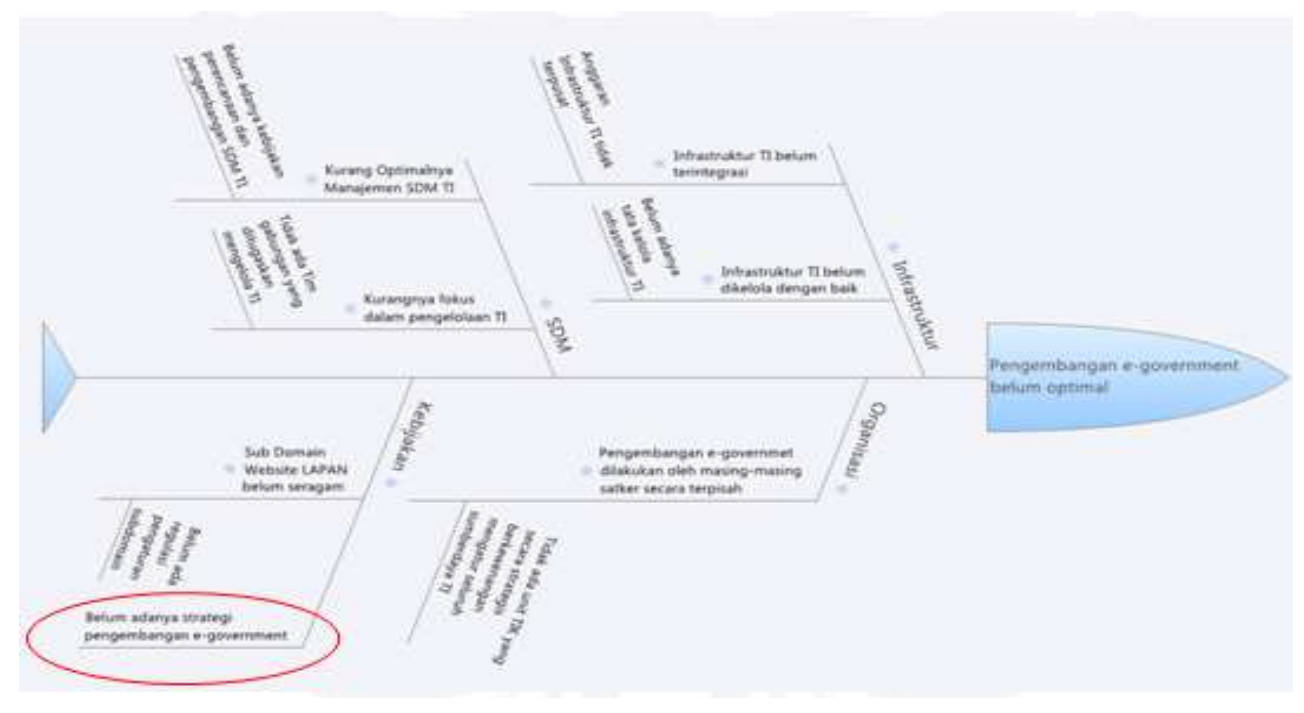

Gambar 1. Fishbone Diagram

Inisiatif e-government oleh pemerintah pusat sudah mulai dilakukan sejak tahun 2001, dengan munculnya Instruksi Presiden No.6 Tahun 2001 tentang Telematika (Telekomunikasi, Media dan Informatika) yang menyatakan bahwa aparat pemerintah harus menggunakan teknologi telematika untuk mendukung good governance dan mempercepat proses demokrasi. [2]

Komitmen pengembangan e-government dikuatkan kembali dengan munculnya Instruksi Presiden No.3 Tahun 2003 tentang Kebijakan dan Strategi Nasional Pengembangan e-government, dimana menginstruksikan agar tiap instansi pemerintah melakukan perumusan strategi/action plan untuk lingkungan instansinya masing-masing. [3]

Esensi pengembangan e-government kian penting dengan adanya program reformasi birokrasi, yaitu proses menata-ulang, mengubah, memperbaiki, dan menyempurnakan birokrasi agar menjadi lebih efisien, efektif dan produktif. Perlunya pengembangan e-government dalam reformasi birokrasi tertuang pada Peraturan Menteri Pemberdayaan Aparatur Negara dan Reformasi Birokrasi No.11 tahun 2011, mengenai indikator keberhasilan reformasi birokrasi, dimana salah satu indikator kinerja keberhasilan reformasi birokrasi adalah adanya pengembangan e-government [4].

LAPAN sebagai instansi pemerintah juga sudah mulai melakukan pengembangan e-government, namun pengembangan yang dilakukan belum optimal, ini bisa dibuktikan dengan beberapa permasalahan sebagai berikut:

Infrastruktur TIK belum dikelola dengan baik, sebagai contoh pada salah satu server web, dalam bulan Januari dan Mei 2012 setidaknya ada 8 kali downtime hal ini dikarenakan sistem keamanan jaringan yang masih lemah, sehingga server mu- dah terserang virus ataupun serangan jaringan lainnya.

Infrastruktur TIK belum terintegrasi, pengadaan investasi infrastruktur TIK dilakukan masingmasing oleh satuan kerja. Hal ini terjadi karena anggaran TIK tersebar pada masing-masing satuan kerja sehingga tercipta pulau-pulau infrastruktur yang tidak saling terintegrasi.

Dari sisi organisasi, LAPAN belum memiliki Unit TIK yang secara strategis memiliki kewenangan untuk mengelola seluruh sumber daya TIK yang dimiliki, saat ini yang ada adalah unit organisasi yang memiliki fungsi memelihara infrastruktur sarana informasi dengan kewenangan yang kecil karena hanya berada pada level eselon IV. Unit tersebut adalah Sub Bagian Pemasyarakatan dan Sarana Informasi Kedirgantaraan (PSIK), dibawah Bagian Humas, Biro Kerjasama dan Humas.

LAPAN belum memiliki kebijakan mengenai pengelolaan nama domain, sehingga menyebabkan beberapa satuan kerja tidak menggunakan domain lapan.go.id. Hal yang paling mendasar penyebab kurang optimalnya pengembangan e-government di LAPAN adalah belum adanya strategi yang efektif yang dapat dijadikan acuan dalam melakukan pengembangan e-government. Atas dasar permasalahan tersebut, maka penulis bermaksud melakukan penelitian yang bertujuan merancang strategi pengembangan $e$-government di LAPAN, dengan menggunakan kerangka kerja PeGI (Pemeringkatan $e$-Government Indonesia).

Dipilihnya PeGI sebagai framework/ kerangka kerja dalam menyusun strategi pengembang $e$ government LAPAN adalah karena PeGI merupakan kerangka kerja yang digunakan untuk melakukan penilaian tingkat implementasi dan pengembangan e-government instansi pemerintah di Indo- 
nesia, dimana LAPAN termasuk didalamnya. Selain itu salah satu tujuan dibuatnya PeGI adalah agar dapat dijadikan acuan dalam pengembangan $e$-government oleh Pemerintah Pusat maupun Pemerintah Daerah. [5]

\section{Metodologi}

Terdapat definisi e-government menurut beberapa sumber, The World Bank Group (2006), mendefinisikan e-government adalah penggunaan teknologi informasi oleh badan-badan pemerintah, seperti: Wide Area Network, Internet, dan Mobile Computing, yang mempunyai kemampuan untuk merubah hubungan dengan warga negara, pelaku bisnis, dan badan pemerintah lainnya. [1]

Dijelaskan juga oleh Mark Forman (2005), pengertian e-government secara umum dapat didefinisikan sebagai penerapan TIK untuk meningkatkan kinerja dari fungsi dan layanan pemerintah tradisional. [6]

Menurut Inpres No.3 Tahun 2003, pengembangan e-government merupakan upaya untuk mengembangkan penyelenggaraan kepemerintahan yang berbasis elektronik, dalam rangka meningkatkan kualitas layanan publik secara efektif dan efisien. Melalui pengembangan e-government dilakukan penataan sistem manajemen dan proses kerja di lingkungan pemerintah dengan mengoptimasikan pemanfaatan teknologi informasi. Inpres ini menginstruksikan agar tiap instansi pemerintah melakukan perumusan strategi/action plan untuk lingkungan instansinya masing-masing.[3]

Menurut Kepmen PAN \& RB No. 11 Tahun 2011, tentang Kriteria dan Ukuran Keberhasilan Reformasi Birokrasi, salah satu kriteria keberhasilan reformasi birokrasi adalah adanya pengembangan e-government pada masing - masing Kementerian/ Lembaga dan Pemerintah Daerah. [4]

Pemeringkatan $e$-Government Indonesia (PeGI) merupakan kegiatan yang diselenggarakan Kementerian Komunikasi dan Informatika yang bertujuan: 1) menyediakan acuan bagi pengembangan dan pemanfaatan TIK di lingkungan pemerintah; 2) memberikan dorongan bagi peningkatan TIK di lingkungan pemerintah melalui evaluasi yang utuh, seimbang, dan obyektif; 3) melihat peta kondisi pemanfaatan TIK di lingkungan pemerintah secara nasional.

Harapan dari pelaksanaan PeGI adalah untuk meningkatkan pengembangan dan pemanfaatan TIK pada lembaga pemerintah di seluruh wilayah Indonesia. Dalam pelaksanaan pemeringkatan, telah ditentukan lima dimensi yang akan dikaji yaitu: kebijakan, kelembagaan, infrastruktur, aplikasi, dan perencanaan. Masing-masing dimensi itu nantinya akan memiliki bobot yang sama dalam penilaian karena semuanya penting, saling terkait dan saling menunjang antara satu dengan yang lainnya. [5]

Dalam surat edaran Menkominfo Nomor: 07/ SE/M.KOMINFO/10/2011 tentang Pemeringkatan E-Government Indonesia disebutkan bahwa dalam rangka peningkatan efisiensi dan efektivitas penerapan TIK di institusi penyelenggara negara, maka Kementerian Komunikasi dan Informatika akan menyelenggarakan Pemeringkatan e-Government Indonesia (PeGI) secara periodik, oleh karena itu dihimbau kepada seluruh institusi penyelenggara negara agar: 1) melaksanakan persiapan untuk mengikuti kegiatan PeGI; 2) melakukan evaluasi diri (self assesment PeGI); 3) mengikuti kegiatan PeGI yang diselengarakan oleh KEMKOMINFO; 4) melakukan langkah perbaikan sesuai dengan rekomendasi assesor PeGI. [7]

\section{Penelitian Sebelumnya}

Yusuf (2008), melaksanakan penelitian untuk mengukur pemeringkatan e-government pada pemerintah tingkat propinsi di Indonesia. Penelitian ini menganalisa 11 (sebelas) propinsi di Indonesia yaitu Propinsi Aceh, Sumatera Selatan, Lampung, Banten, Jawa Barat, Jawa Tengah, DI Yogyakarta, Jawa Timur, Kalimantan Barat, NTT, dan Sulawesi Tenggara. Penilaian didasarkan pada skala 1 sampai dengan 4 yang diberikan pada 33 indikator yang dikelompokan menjadi 5 dimensi. Nilai maksimal adalah 132 dan minimal adalah 33. Proses pemeringkatan dilakukan berdasarkan perhitungan nilai total dari semua dimensi yang ada. [8]

TABEL 1

\begin{tabular}{clc}
\multicolumn{3}{c}{ TABEL 1} \\
\hline Peringkat & \multicolumn{1}{c}{ Propinsi } & Nilai \\
\hline 1 & D.I Yogyakarta & 96.01 \\
2 & Jawa Timur & 94,66 \\
3 & Jawa Barat & 85.00 \\
4 & Banten & 75.00 \\
6 & Aceh & 73.67 \\
7 & Kalimantan Barat & 69.66 \\
8 & Sumatera Selatan & 63.32 \\
9 & NTT & 60.00 \\
10 & Sumatera Selatan & 63.32 \\
11 & Lampung & 42.66 \\
\hline
\end{tabular}

Aryani (2009) melakukan evaluasi terhadap sistem penilaian Pemeringkatan e-Government Indonesia dengan pengujian perluasan assesment yang dilakukan pada tingkat pemerintah kabupaten/Kota. Mengusung pertanyaan riset "Seberapa jauhkah kesesuaian kerangka kerja pemeringkatan e-government di Indonesia (PeGI) untuk diterapkan pada tingkat kabupaten/ kotamadya?".

Penelitian ini mengambil sampel kota Tangerang Selatan. Hasil dari analisa dampak indikator tersebut didapatkan kesimpulan bahwa seluruh indikator penilaian masih sesuai dan relevan untuk diterapkan pada penilaian tingkat kabupaten/kota- 
madya. Aryani juga memberikan saran penambahan indikator pada dimensi aplikasi yaitu indikator alternatif saluran layanan dan respon masyarakat [9].

Priyatna (2007), melakukan perancangan model bisnis yang cocok bagi Instalasi Lingkungan Cuaca (ILC). Secara garis besar, tugas dan kewajiban ILC yaitu melakukan perolehan (acquisition), penyimpanan data satelit lingkungan dan cuaca, serta melakukan penelitian di bidang inderaja. Model bisnis yang diusulkan menggunakan model $e$ business. Model $e$-business yang digunakan mengkombinasikan antara model e-business Esichaikul dan Chavananon; serta Kalokota dan Robinson, tahapan tersebut dijelaskan sebagai berikut: Tahap 1: Analisis Peluang Bisnis, Tahap 2: Analisis Infrastruktur Teknologi Informasi; Tahap 3: Solusi perancangan model bisnis dan arsitektur sistem, Tahap 4: Persiapan membuat petunjuk tentang peraturan, kebijakan, dan diseminasi untuk memudahkan implementasi e-government. Melalui kegiatan penelitian tersebut, maka untuk pola solusi bisnis yang dipilih yaitu: application patern for acces integration, self service, application integration, extended enterprise, information aggregation dan collaboration [10].

\section{Kerangka Pikir Penelitian}

Secara hukum, kebutuhan pengembangan $e$-government di LAPAN muncul sebagai dampak diterbitkannya Inpres No.3 tahun 2003 dan Peraturan Menteri PAN dan RB No.11 tahun 2011. Hal ini diperkuat juga dengan urgensi dari tujuan dan manfaat yang dapat diambil bila melakukkan pengembangan e-government. Pemilihan PeGI sebagai kerangka kerja perancangan strategi pemgembangan e-government karena sesuai dengan tujuan pelaksanaannya yaitu dapat dijadikan acuan bagi pengembangan e-government hal ini diperkuat dengan adanya surat edaran Kemkominfo kepada seluruh instansi pemerintah termasuk LAPAN untuk dapat mengikuti PeGI (Pemeringkatan e-Government Indonesia). Strategi pengembangan e-government disusun berdasarkan gap analisis antara kondisi saat ini dengan kondisi yang diharapkan.

Metode yang digunakan bersifat kualitatif deskriptif dengan teknik pengambilan data melalui studi dokumen, observasi, dan focus group discussion (FGD).

\section{Hasil dan Analisa}

Pada saat melakukan penilaian penerapan e-government berdasarkan pedoman penilaian PeGI, didapatkan bahwa untuk target kondisi yang diharapkan, yang layak untuk dijadikan target hanyalah level 4, karena statement untuk kondisi level 2 dan 3 banyak mengandung kalimat negatif. Menentu-

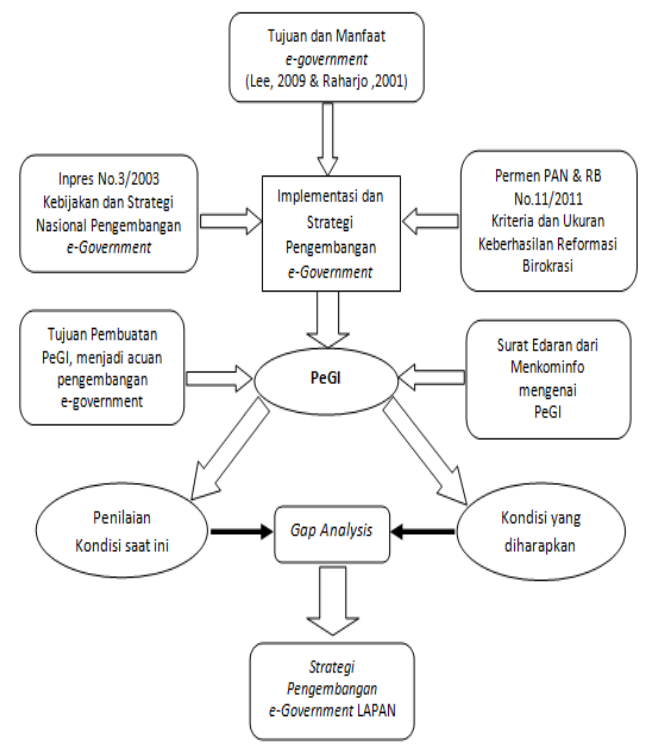

Gambar 2. Kerangka Pikir Penelitian

kan target kondisi langsung pada rata-rata level 4 merupakan hal yang hampir tidak mungkin untuk dicapai. Untuk itu penulis mengajukan usulan revisi terhadap pedoman penilain PeGI dengan cara menghilangkan unsur kalimat negatif pada pedoman penilaian PeGI untuk level 2 dan 3. Dokumen usulan revisi inilah yang akan dijadikan pedoman penilaian e-government pada Karya Akhir ini. Usulan ini disusun agar target kondisi dapat ditentukan secara bertahap tidak langsung pada level 4. Hal ini sesuai dengan referensi dari tahapan level maturitas Proses TI pada COBIT (Yuwono, 2009), dimana peningkatan level dilakukan secara berjenjang dengan statement kondisi pada masing-masing level tidak mengandung kalimat negatif. Berdasarkan penilaian yang telah dilakukan didapatkan hasil yang tercantum pada Tabel 2 .

TABEL 2

\begin{tabular}{clcc}
\multicolumn{4}{c}{ HASIL SELURUH DIMENSI } \\
\hline No & \multicolumn{1}{c}{ Dimensi } & As Is & To Be \\
\hline 1 & Kebijakan & 1.25 & 3 \\
2 & Kelembagaan & 2 & 3.2 \\
3 & Infrastruktur & 1.86 & 3 \\
4 & Aplikasi & 2.5 & 3,7 \\
5 & Perencanaan & 1.8 & 3 \\
\hline & Rata-rata & 1.88 & 3.18 \\
\hline
\end{tabular}

Untuk dimensi kelembagaan, nilai As Is condition adalah 2 dan nilai To Be condition-nya 3,2. Saat ini organisasi pengelola TIK yang dimiliki LAPAN berada pada level eselon IV yang bernama Sub Bagian Pemasyarakatan dan Sarana Informasi Kedirgantaraan (PSIK). Posisi pada eselon IV menyebabkan organisasi TI tidak memiliki kewenangan yang luas serta anggaran yang tidak mandiri. Untuk sisi tugas dan fungsi serta ketersediaan SOP, 
saat ini LAPAN sudah memiliki namun belum lengkap. SDM TIK di Sub Bag PSIK saat ini hanya 5 personel sehingga masih kurang memadai dan rencana pengembangan SDM TIK belum terdokumentasi dengan baik. Untuk kondisi yang diharapkan LAPAN memiliki Organisasi TIK yang jelas strukturnya dan merupakan unit tersendiri serta memiliki wewenang yang tinggi minimal berada pada eselon II. Hal tersebut disesuaikan pula untuk penyusunan tugas dan fungsi, SOP, ketersediaan SDM dan rencana pengembangan SDM-nya.

Untuk dimensi infrastruktur, nilai As Is condition adalah 1.86 dan nilai To Be condition-nya 3 . Saat ini sebagian besar unsur penilaian (sub dimensi) pada dimensi infrastruktur sudah dimiliki dan dilaksanakan, namun belum dikelola dengan baik dan konsisten. Adapun sub dimensi untuk infrastruktur adalah data center, jaringan data, keamanan, fasilitas pendukung, disaster recovery, pemeliharaan TIK dan inventaris peralatan TIK. Untuk kondisi yang diharapkan setiap sub dimensi sudah dimiliki, dilaksanakan, dikelola serta dilakukan evaluasi secara periodik.

\begin{tabular}{clccc}
\multicolumn{5}{c}{ TABEL 3 } \\
GAP ANALYSIS \\
\hline No & Dimensi & As Is & To Be & Gap \\
\hline 1 & Kebijakan & 1.25 & 3 & 1,75 \\
2 & Kelembagaan & 2 & 3.2 & 1,2 \\
3 & Infrastruktur & 1.86 & 3 & 1,14 \\
4 & Aplikasi & 2.5 & 3,7 & 1,2 \\
5 & Perencanaan & 1,8 & 3 & 1,2 \\
\hline & Rata-rata & 1.88 & 3.18 & 1,3 \\
\hline
\end{tabular}

Untuk dimensi aplikasi, nilai As Is condition adalah 2,5 dan nilai To Be condition-nya 3,7. Saat ini dimensi aplikasi merupakan dimensi yang memiliki tingkat implementasi e-government paling tinggi. Sebagian besar unsur penilaian (sub dimensi) sudah dimiliki dan dilaksanakan, namun belum memiliki dokumentasi yang baik. Adapun sub dimensi yang dimaksud adalah situs web, aplikasi bidang pelayanan umum, aplikasi bidang administrasi dan manajemen umum, aplikasi bidang administrasi legislasi, aplikasi di bidang manajemen pembangunan, aplikasi dibidang manajemen keuangan, aplikasi di bidang manajemen kepegawaian, dokumentasi, inventarisasi aplikasi TIK, dan interoperabilitas aplikasi. Untuk kondisi yang diharapkan bahwa setiap sub dimensi sudah dimiliki dan dikelola berdasarkan SOP serta adanya perawatan untuk setiap aplikasi yang dimiliki.

Untuk dimensi perencanaan, nilai As Is condition adalah 1,8 dan nilai To Be condition-nya 3 . Saat ini fungsi perencanaan TIK dilaksanakan oleh Sub Bagian PSIK namun belum dapat melibatkan seluruh stakeholder yang ada terutama unsur pimpinan. Sistem perencanaan yang dilaksanakan masih bersifat ad hoc, dokumentasi Master Plan TIK belum lengkap dan belum dilaksanakan, rencana

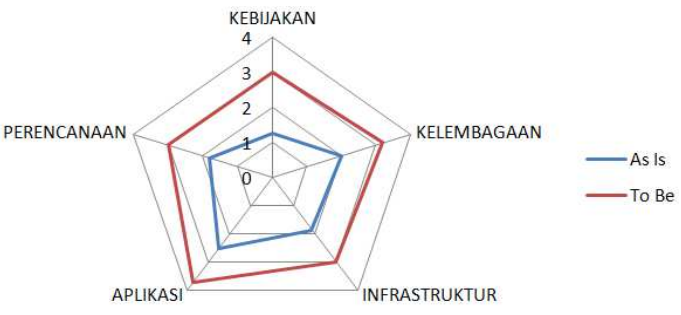

Gambar 3. Hasil Seluruh Dimensi

implementasi master plan TIK belum terdokumentasi dengan baik, dan anggaran untuk pembiayaan TIK saat ini masih kurang memenuhi kebutuhan secara keseluruhan. Kondisi yang diharapkan, bahwa setiap sub dimensi dalam dimensi perencanaan ini dapat dimiliki, dikelola dan dilaksanakan dengan baik dengan dokumentasi yang baik pula.

Dari hasil Gap Analysis didapatkan bahwa dimensi yang memiliki gap paling besar adalah Kebijakan dengan nilai 1,75 (Tabel 3). Hal ini menunjukan bahwa tingkat implementasi e-government pada sisi kebijakan paling kurang dibanding dengan dimensi yang lainnya. Dikarenakan seluruh dimensi penilaian masih dibawah target maka strategi pengembangan disusun untuk seluruh dimensi penilaian. Strategi disusun sesuai dengan target kondisi yang diharapkan dengan berdasarkan baseline kondisi saat ini.

\section{Strategi Pengembangan e-Government}

\section{Dimensi Kebijakan}

- Membentuk Komite TIK instansi yang terdiri dari para eselon I dan II dilingkungan LA-PAN yang memiliki kewenangan untuk:

- Membangun manajemen/proses kebijak-an di bidang TIK yang konsisten.

- Menentukan Visi dan Misi instansi yang berkaitan dengan TIK sebagai acuan da-lam menentukan strategi dalam pengem-bangan TIK.

- Membentuk Tim Teknis dibawah koordinasi Komite TIK instansi terdiri dari perwakilan pengelola TIK seluruh satker LAPAN. Tim ini memiliki tugas:

- Menyusun strategi penerapan kebijakan TIK yang mengacu pada visi dan misi instansi agar tercipta keselarasan.

- Menyusun pedoman kebijakan TIK.

- Menyusun peraturan penerapan kebijakan TIK.

- Menyusun dokumen keputusan instansi yang terkait penerapan kebijakan TIK.

- Menyusun dokumen usulan skala prioritas penerapan kebijakan TIK. 
- Melaksanakan kegiatan evaluasi TIK secara terstruktur.

Dimensi Kelembagaan

- Membentuk unit organisasi pengelola TIK yang mandiri dengan tugas dan fungsi yang jelas serta memiliki kewenangan yang tinggi, minimal berada pada level eselon II.

- Menyusun tugas dan fungsi organisasi TIK secara jelas dan lengkap sesuai struktur organisasi yang sudah direkomendasikan.

- Menyusun SOP TIK dengan jelas, dan didokumentasikan dengan baik.

- Menyusun dokumen perencanaan SDM TIK LAPAN termasuk jabatan, uraian tugas, dan kompetensinya.

- Menyusun dokumen rencana pengembangan SDM TIK LAPAN.

Dimensi Aplikasi

- Melakukan pengembangan data center yang terintegrasi dengan baik dengan fasilitas dan aplikasi pendukung yang memadai.

- Melakukan pengembangan jaringan TIK LAPAN dengan mempertimbangkan unsur kemudahan akses user.

- Menyusun dokumen mekanisme keamanan jaringan yang dievaluasi secara periodik.

- Membangun fasilitas pendukung infrastruk-tur TIK yang memadai.

- Menyusun dokumen disaster recovery yang telah terdokumentasi dengan baik dan sudah dilakukan testing.

- Menyusun mekanisme dan jadwal perawatan TIK.

- Melakukan inventarisasi peralatan TIK dengan dokumentasi yang baik.

Dimensi Aplikasi

- Melakukan pengembangan situs web yang mendukung fitur interaktif dengan pengguna serta terintegrasi dengan back office.

- Menyusun SOP dan jadwal pemeliharaan aplikasi untuk seluruh kategori aplikasi fungsional utama.

- Melakukan penyusunan dokumentasi pro-gram dan prosedur terhadap seluruh aplikasi yang dimiliki.

- Melakukan kegiatan inventarisasi aplikasi TIK secara periodik dan menyusun dokumen inventaris sesuai dengan urutan aplikasi yang paling kritikal.

- Membangun aplikasi integration layer untuk dapat menjembatani aplikasi-aplikasi yang berasal dari kategori fungsional utama yang berbeda agar dapat melakukan interoperabilitas.

\section{Dimensi Perencanaan}

- Memberikan tugas pada unit pengelola TIK Pusat untuk dapat mnegkoordinasikan perencanaan TIK dengan melibatkan seluruh stakeholder.

- Menyusun dokumen mekanisme perencanaan TIK dengan melibatkan satker-satker.

- Menyusun dokumen Master Plan TIK yang mengandung seluruh unsur dimensi PeGI.

- Menyusun dokumen perencanaan rinci Mas-ter Plan TIK.

- Menyusun perencanaan anggaran TIK yang sesuai dengan kebutuhan organisasi dan dituangkan dalam RKAKL.

\section{Implikasi Penelitian}

\section{Aspek Manajerial}

Dengan mengetahui tingkat implementasi $e$-government berdasarkan kerangka kerja PeGI untuk kondisi saat ini, kondisi yang diharapkan serta strategi pencapaian menuju kondisi yang diharapkan, dapat dijadikan masukkan bagi pihak manajemen sebagai acuan dalam melakukan pengembangan $e$ government dilingkungan LAPAN. Hal ini juga dapat dijadikan sebagai langkah persiapan dalam mengikuti PeGI yang diselenggarakan oleh Kemkominfo.

\section{Aspek e-government}

Penelitian yang penulis lakukan memberikan saran terhadap perbaikan/revisi dari Pedoman Penilaian Kerangka Kerja PeGI, agar dalam menentukan target kondisi implementasi e-government yang diharapkan dapat dilakukan secara berjenjang, tidak langsung pada level 4. Usulan perbaikan dilakukan dengan cara menghilangkan kalimat negatif pada setiap level stetement kondisi untuk masing-masing sub dimensi.

\section{Aspek Penelitian Selanjutnya}

Pada penelitian ini penulis memberikan saran mengenai usulan revisi Pedoman Penilaian PeGI. Pedoman Penilaian PeGI yang penulis usulkan disesuaikan dengan kondisi organisasi LAPAN. Untuk menguji apakah usulan refisi Pedoman Penilaian PeGI tersebut bersifat general, disarankan untuk penelitian selanjutnya untuk menguji usulan Pedoman Penilaian PeGI tersebut untuk instansi pemerintah lain terutama untuk Pemerintah Provinsi ataupun Pemerintah Kabupaten/Kota. 


\section{Kesimpulan}

Dari hasil analisis strategi pengembangan $e$-government menggunakan kerangka kerja PeGI studi kasus pada Lembaga Penerbangan dan Antariksa Nasional didapatkan kesimpulan sebagai berikut:

1. Hasil penilaian level implementasi e-government LAPAN berdasarkan kerangka kerja PeGI saat ini adalah 1,88 yang berarti masih "Kurang". Sedangkan kondisi ideal yang diharapkan mencapai level 3,18 yang berarti "Baik".

2. Dari hasil Gap Analysis didapatkan bahwa dimensi yang memiliki gap terbesar adalah $\mathrm{Ke}$ bijakan dengan nilai 1,75 . Hal ini menunjukan bahwa tingkat implementasi e-government pada sisi kebijakan paling kurang dibanding dengan dimensi yang lainnya. Dikarenakan seluruh dimensi penilaian masih dibawah target maka strategi pengembangan disusun untuk seluruh dimensi penilaian. Strategi disusun sesuai dengan target kondisi yang diharapkan dengan berdasarkan baseline kondisi saat ini.

3. Untuk mencapai kondisi level penerapan $e$ Government yang diharapkan, memerlukan adanya strategi yang tepat dan sesuai dengan lingkungan organisasi. Adapun usulan strategi pengembangan $e$-Government LAPAN telah dijabarkan pada Bab Pembahasan.

\section{Referensi}

[1] World Bank, e-government for All - Review of International Experience with Enhancing Public.
[2] Presiden RI, (2003), Instruksi Presiden No.6 Tahun 2001 tentang Telematika (Telekomunikasi, Media dan Informatika), Jakarta.

[3] Presiden RI, (2003), Instruksi Presiden No.3 Tahun 2003 tentang Kebijakan dan Strategi Nasional Pengembangan e-Government, Jakarta.

[4] Kemenpan, (2011), Peraturan Menteri Pemberdayaan Aparatur Negara dan Reformasi Birokrasi No.11 tahun 2011 tentang Indikator Keberhasilan Reformasi Birokrasi, Jakarta.

[5] Kemkominfo (2012), Pemeringkatan e-government Indonesia [slide Materi Dimensi Pemeringkatan dan Formulir Assesment]. Jakarta.

[6] Forman, Mark (2005), e-Government: Using IT to transform the effectiveness and efficiency of government.

[7] Kemkominfo, (2011), Surat Edaran Menteri Komunikasi dan Informatika Nomor:07/SE/ M.KOMINFO/10/2011 tentang Pemeringkatan e-Government Indonesia (PeGI). Jakarta.

[8] Yusuf, Suwidhi (2008), Pemeringkatan Egovernment Indonesia: Tesis, Fakultas Ilmu Komputer, MTI, Universitas Indonesia.

[9] Aryani, Pipin Farida (2009), Kajian Kerangka Kerja Pemeringkatan eGovernment di Ting-kat Kabupaten/ Kotamadya: Tesis, Fakultas Ilmu Komputer, MTI, Universitas Indonesia.

[10] Priyatna, (2007), Pengembangan e-Government Pada Instalasi Lingkungan dan Cuaca Lembaga Penerbangan dan Antariksa Nasional dengan Mengadopsi Model e-Business: Studi Kasus Pengelolaan Data Satelit NOAA (The National Oceanic and Atmospheric Administration), Tesis, Fakultas Ilmu Komputer MTI, Universitas Indonesia, Jakarta 
Fahmi Alusi, et al., Penyusunan Strategi E-Government 39 